\title{
IAMJ
}

INTERNATIONAL

AYURVEDIC

MEDICAL JOURNAL

\section{AYURVEDIC APPROACH TO PREVENTION OF STROKE \& HEART DISEASES FROM DIABETES MELLITUS}

\author{
Priyanka V. Dekate
}

MD Kayachikitsa, Assistant Professor, Siddhakala Ayurved Mahavidyalaya, Sangamner Maharashtra, India

Corresponding Author: priyankav635@gmail.com

https://doi.org/10.46607/iamj1309052021

(Published Online: May 2021)

Open Access

(C) International Ayurvedic Medical Journal, India 2021

Article Received: 16/04/2021 - Peer Reviewed: 04/05/2021 - Accepted for Publication: 05/05/2021

Check for updates

\begin{abstract}
Madhumeha (Diabetes) is attracting the world as a non-infectious pandemic/epidemic. The prevalence of Diabetes is on the rise, more alarmingly in the developing country. Ranked $7^{\text {th }}$ among leading causes of death. This multiplying incidence of CVS \& heart diseases. Now days Ayurveda is of wise important to get swasthya, to prevent heart diseases \& stroke from DM. The objectives of study are to evolve standard Ayurvedic drug \& preventive measures for Madhumeha. This study is based on review of Ayurvedic Samhitas \& previous research work. DM is the $6^{\text {th }}$ leading cause of death in the world. Therefore, attempt should be made to balance the Dehamanas prakruti \& normal state of physiological energy to prevent Diabetes Mellitus. Dinacharya (Daily regimen), Ashtavidha aahara vidhi Aayatana \& herbo mineral drugs with Yogasana help to prevent diabetes \& its related complication.
\end{abstract}

Keyword: Madhumeha, stroke, Heart diseases.

\section{INTRODUCTION}

Ayurveda in fact the first medical science that identified, diagnosed and managed Madhumeha while claiming it is incurable much earlier to modern science. Ayurveda can give effective solutions to the burning problem (Madhumeha) due to its special treatment methods based on scientific fundamentals 
and through utilization of highly effective and safe herbo-mineral preparations, yoga, daily regimen etc. Madhumeha is the disease spreading in civilization; it existed in those people who are greedy and lazy, stressful lifestyle.

As per recent study, India will be the Diabetes capital of the world in the near future. Diabetes mellitus is the $6^{\text {th }}$ leading cause of death in the world. As per WHO assessment there are 150 million diabetes patients worldwide. WHO reported at the end of 2025 A.D. the incidence of DM might increase by threefold as on today.

If not managed properly, people with Madhumeha are, 30 to 40 times more likely to undergo major amputation.

25 times more likely to develop blindness.

17 times more likely to develop kidney diseases.

2 to 4 times more likely to develop Myocardial infarction.

2 times more likely to develop a heart disease and stroke than non- diabetics.

At least $68 \%$ of people of age 65 or older with diabetes die from heart disease, $16 \%$ die from stroke. The American Heart Association considers diabetes to be one of the major controllable risk factors for cardiovascular disease. The present study deals with the standard ayurvedic drugs and other preventive measures against diabetes and its complications like stroke and heart diseases. The basic pathophysiology behind stroke and heart disease (in Diabetes) is evaluated.

\section{Aim and Objectives:}

1) To evolve standard ayurvedic drugs and other preventive measures in Madumeha.

2) To study pathogenesis of stroke and heart disease in Diabetes mellitus.

\section{Materials and Methods:}

The study is based on the ancient ayurvedic texts, samhitas and related research articles.

The additional information is also collected from internet (related websites)

How the people with diabetes mellitus are at increased risk for cerebro-vascular episodes (stroke)?
High blood sugar level (DM) is the common silent killer. Uncontrolled high blood sugar levels can cause stroke, kidney damage, heart attacks etc. This is called as end organ damage because these are terminal arteries which have no other collateral circulation. Once they are blocked or damaged the organ or the tissue, they supply dies without oxygen and nutrients.

Development of stroke in Diabetic patients: -

Insulin is the only hormone that reduces blood sugar level and it is called as the anti-diabetic hormone. Insulin has a vital role in the synthesis of fatty acids and triglycerides also. It promotes the transport of excess glucose into cells particularly liver cells. This glucose is utilized for the synthesis of fatty acids and triglycerides. Insulin promotes the storage of fat in adipose tissue by inhibiting the enzymes which degrade triglycerides. The lack or resistance to insulin in diabetic patients may lead to increase in triglycerides.

There are several possible mechanisms wherein diabetes leads to stroke. These include, 1) vascular endothelial dysfunction, 2) increased early-age arterial stiffness, 3) systemic inflammation and thickness of capillary basal membrane, 4) abnormality in early left ventricular diastolic filling are commonly seen in type 2 DM Patients.

Nitric oxide mediates vasodilatation and its decreased availability can cause endothelial dysfunction and trigger a cascade of atherosclerosis. NO- mediated vasodilatation is also impaired in individuals with diabetes, possibly due to increased inactivation of NO or decreased reactivity of the smooth muscles to NO. Individual with type $2 \mathrm{DM}$ have stiffer arteries and decreased elasticity compared with subjects having normal BSL. Hyperglycemia is a common symptom presented in early acute stroke phase. Hyperglycemia results in increased lactate production in brain reduce salvage and penumbral tissue causing greater infarcts. In Ayurveda the term atherosclerosis is called as Dhamani-pratichaya. This causes Strotovarodhaobstruction of the channels in due course and hence high blood pressure. When the blood vessels to the brain damaged by high blood pressure eventually leads to micro tears (hemorrhages) causing interrupted 
blood oxygen supply to the brain causing a stroke death of the area or brain where blood circulation has stopped.

\section{Heart attack and DM:}

Over time, high blood glucose from diabetes can damage blood vessels and nerves that supply heart. If you have diabetes, other risk factors add to chances of developing heart disease or having stroke are,

\section{Smoking}

\section{HTN}

\section{Abnormal cholesterol levels (atherosclerosis) \\ Obesity and belly fat}

\section{Family history of heart disease.}

High blood sugar levels responsible for development of atherosclerosis unstable plaque in the wall of coronary arteries that ruptures, resulting in acute thrombosis and MI. Hence be aware of all these things.

\section{Ayurvedic concept of prevention:}

Ayurveda advise the well-balanced state of Dehamanas -prakruti - a normal state of three physiological energies i.e. Vata, Pitta, Kapha.

The imbalanced Vata dosha leads sudden anxiety, worry, grief, agitation, depression, hyperactivity. The lifestyle changes such as smoking, drug abuse, alcohol intake causing derangement of vata in Pakwashaya and in the whole body causes persistent spasm of blood vessel wall and increased blood sugar level which can be compared with modern physiology of adrenalin and cortisol and histamine like substances, increased angiotensin, it produces prolonged stress causing sudden increase in BSL and vasospasm of coronary, cerebral and peripheral arteries eventually high blood pressure.

The Pitta can be vitiated by intake of heavy, spicy, too sweet food, hyperactivity causes pachak dhatwagnimanya- dhatushaithilya and Prameha occur.

The Kapha can be vitiated by increased fat and sugar intake, sedentary life. It also increases the risk of cholesterol -fat deposition causing atherosclerosis in the arteries.

The essentials of prevention of strike and heart disease from diabetes mellitus based on these 3 factors,
Prevention from stress - Adhi means problems in life, vyadhi - worry, Upadhi- tension. Pradnyaparadha Faulty intellect causes imbalances of thoughts and behavior, worry, depression, addiction, etc. use of logical and rational thinking helps to maintain the equilibrium and control of our mind is recommended. This is done by reading to adopting good philosophy, avoiding impulsive reactions of life, smrutiremembering the good karmas- actions that bring health and happiness in life.

Control on our senses and pleasures - avoiding indulgence in addictive substances and activities: Asatmendriyartha samyoga. Ayurveda says that too much, too less or perverted abnormal contact of our senses with objects causes disease. Indulgence in addictive drugs, smoking, alcohol or drugs, excessive or perverted sexual activity, even exercises or ports, frightful tense or sad movies, or even keeping the company of very aggressive, loud, or critical people.

Kalaparinama: environmental factors such as exposure to pollution, chemicals, etc.

Ayurvedic herbal preparations:

1) Guduchi - The herb which balances the vitiated Vata (Air) due to its hot potency \& sticky property. It also helps in balancing the Pitta (Fire) \& Kapha (Water) due to its bitter \& astringent taste. So it helps in balancing the all three Doshas (Humors). It also has some rejuvenating (Rasayana) properties. It naturally keeps the body temperature normal.

The isoquinololine alkaloid rich fraction from stem, include palmatine, jatorrhizine and magnoflorine which have been reported for insulin mimicking and insulin releasing effect.

Besides tinosporin, isocolumbin, palmatine, tinocordiside, cordioside, Beta-sitosterol compounds present in stem and root which are also reported to possess antidiabetic, antihyperlipidemic, antioxidant properties.

2) Karvellak - The fruits, leaves and roots of karvellak have long termed used in India as a folk remedy for diabetes. The fruit and seeds yield polypeptide constituents to be similar in bovine insulin. It has been shown to have a 
hyperglycemic effect in all types of diabetes. It also promotes peripheral utilization of glucose. The main hypoglycemic principle from this plant is charantin which has more potent action than that of tobutamide.

3) Methica - The mode of action of the dietary fibers is by decreasing the rate of gastric emptying and decreasing the absorption of glucose from the small intestine.

The research has relieved that fenugreek seeds that in peripheral insulin activity without increasing insulin levels and fenugreek seeds have hypocholestraemic and hypoglyceradaemic effects.

4) Jambu - Extracts of bark seeds and also leaves are used in the treatment of diabetes. The bark extract is reported to have effect on glycogenolysis and glycogen storage in animals. Alkaloid jambosine as well essential oil is found in this drug diminishes the quantity of sugar in urine and also reduces thirst in diabetes. Charaka stated Jambu as Vataharanam shreshtham.

5) Haridra and Daruharidra - Curcumin is used for the reduction of cholesterol level. Dhanvantari nighantu and Vruddha vagbhatta termed Haridra as an anti-diabetic drug. Berberin found in daruharidra is having anti-diabetic activity.

6) Amalaki - It is used as a rasayana, brain tonic, chakshushya, diuretic. The reference of antidiabetic activity of amalaki is found in Bhavaprakash and Raj Nighantu.

7) Madanphala - Madanphala is having sukshma, vyavayi, vikasi guna. Thus it reduces the excessive medas.

8) Shilajatu -it is said to be a rasayan or rejuvenator which helps in hypertension and reduces risk of heart diseases.

9) Medohar guggula- is the specific weight and fat control herbal medicine in Ayurveda.

10) Trifala guggula - a herbal medicine for no. of medical conditions, rich antioxidant.

11) Lekhana guggula - comprises guggula, Musta, Rason, Kutki, Shunthi, Guduchi satva. It is used to manage IHD.

\section{The ayurvedic ahara niyaman:}

'Ashtavidha-avarvidhiayanani'(Charaka) - the food should be ushna, snigha, in proper amount, allowing enough time between meals, with without contradictory foods, not with too hurry or too slowly, with only attention to it, not too hot or too cold, with its respect for yourself. Acharya Sushruta had also given Dwadashayatan for food intake.

Panchakarma Procedures

Role of Madhutailik Basti:

The contents of madhutailik basti are madhu, til tail, erandmula kwatha, shatpushpa churna madanphala pippali churna, saindhava lavan, described by Sushrutacharya as one of the kinds of Niruhabasti.

Shirodhara: Various medicated oil or cold milk is poured at a specific slow rate on the forehead to relax the mind and reduce blood pressure.

Approach towards Yoga, Pranayam:

Ayurveda recommends gentle deep breathing exercise to fill the lungs with oxygen which then helps good circulation and oxygenation of blood vessels, heart and brain other organs of the body. (Kapalbhati, Bhramari, etc)

1) Sarvangasan: It helps in metabolizing sugar and improving functions of pancreas. It stimulates various glands particularly thyroid, parathyroid glands.

2) Kapalbhati: facilitates the body to inhale a good amount of oxygen that purifies blood and is beneficial for diabetic patients.

The other asanas such as Dhanurasan, Halasan, Paschhimottanasan, Bhujangasan, Chakrasan, Vajrasan also help to regulate blood sugar level and reducing belly fat too.

Result: Diabetes is a metabolic disorder affecting all systems in the body. The modern medicines having no. of side effects including poor absorption of nutrients and its utilization as well. Therefore, there is need to develop the ayurvedic preventive measures against the disease. The adoption of above regimes will definitely help us to control the sufferings. 


\section{DISCUSSION}

In ayurveda, this health disorder is called as madhumeha. Due to the adverse effects that can be created by elevated blood sugar level to each and every important organ of human body, this is referred as maharogas in ayurveda. To prevent high blood sugar and diabetic complications, ayurveda recommends the herbal compounds and use restricted diet planes, exercises and better lifestyle modifications (Aharvihara sankalpana). To optimize the Diabetes related complications this is mandatory to follow ayurveda regimens and activities.

\section{CONCLUSION}

All forms of diabetes have very serious effects on health. In addition to the consequences of abnormal metabolism of glucose there are a number of longterm complications associated with the disease, which are responsible for morbidity, disability and premature deaths in young adults. Dinacharya (Daily regimen), Ashtavidha aahara vidhi Aayatana \& herbo-mineral drugs with Yogasana help to prevent diabetes \& its related complications.

\section{REFERENCES}

1. Charak samhita, chikitsa sthana, Pramehachikitsadhyaya 6, 46/47, edited by Dr. Kashinath Shastri, Dr. Gorakhnath Chaturvedi, edition reprint 2002, Chaukhambha prakashan, page no. $227-$ 244

2. Charak samhita, chikitsa sthana, Deerghamjivitaya adhyaya $1^{\text {st }} 17 / 82$, edited by Dr. Kashinath Shastri, Dr. Gorakhnath Chaturvedi, edition reprint 2002, Chaukhambha prakashan, page no. 6-8

3. Sushruta samhita, Chikitsasthana, Pramehachikitsa 11/ 12, edited by Dr. Ambikadatta Shastri $8^{\text {th }}$ edition,Chaukhambha Sanskrit sansthana 1993 page no.451-453

4. Dr. Vijay Patrikar, Sampurna Swastha vritta vigyan edition- Godavari prakashan, edition $1^{\text {st } 2005, ~ p u b . ~}$ Godavari publisher Part 2, page no. 1-110

5. Acharya Priyavat Sharma, Dravyaguna Vjnyana edition 2012, Chaukhmbha Bharati Akadami part 2 page no: 162,345, 423, 437, 650, 686, 658, 684

6. Gyton \& Hall, edition 2010, Textbook of Human Physiology, chapter 78, pp.886
7. Dietary management of type $2 \mathrm{DM}$ with cardiac risk factors by Renu Batra, March 200, pp186.

8. Yadaiha P, Effect of basti treatment in jataj prameha , sachitra Ayurveda May 1987 pp.98-101

9. WHO,1999, Definition, Diagnosis and its complications, WHO/NCD/NCS/99.2

\section{Source of Support: Nil \\ Conflict of Interest: None Declared}

How to cite this URL: Priyanka V. Dekate: Ayurvedic Approach To Prevention Of Stroke \& Heart Diseases From Diabetes Mellitus. International Ayurvedic Medical Journal \{online\} 2021 \{cited May, 2021\} Available from: http://www.iamj.in/posts/images/upload/1027_1031.pdf 